\title{
European
}

Psychologist

\section{Growing Primacy of Human Agency in Adaptation and Change in the Electronic Era}

\author{
Albert Bandura \\ Stanford University, Stanford, CA, USA
}

\begin{abstract}
The extraordinary advances in electronic technologies and global human interconnectedness present novel adaptational challenges and expanded opportunities for people to shape their social future and national life. The present article analyzes these peroasive transformational changes from an agentic theoretical perspective rooted in the exercise of perceived personal and collective efficacy. By acting on their efficacy beliefs, people ply the enabling functions of electronic systems to promote their education,
\end{abstract}

health, affective well-being, worklife, organizational innowativeness and productivity and to change social conditions that affect their lives. Technology influences, and is influenced by, the sociostructural nature of societies. The codetermining sociostructural factors affect whether electronic technologies and giobalization serve as positioe forces that benefit all or divisive ones in human lives.

Keywords: Cyberworld, globalization, human agency, self-efficacy, self-regulation.

The revolutionary advances in electronic technologies are changing our world in fundamental ways. Life in the rapidly evolving cyberworld transcends time, distance, place, and national borders, and alters our conceptions of them. Instant communicative access worldwide is also transforming the nature, reach, speed, and loci of human influence. It alters how people communicate, educate, work, relate to each other, and conduct their business and daily affairs. In managing their various aspects of life, people now have the benefit of vastly expanded and diverse social networks. These rapidly evolving realities present new adaptational challenges and enlarged opportunities for people to exercise some measure of control over their personal development and to shape their national life.

Wrenching changes that dislocate and restructure lives are not new in history. What is new is the boundless scope and accelerated pace of human transactions and the growing globalization of human interconnectedness. Technology is but one component embedded in an intricate network of sociostructural influences. The development of new technologies, their applications, and societal impact are determined, in large part, by nontechno- logical sociostructural factors operating interdependently within the larger totality of influences. No single factor in this multicausality plays a determining role in shaping the nature of society. Any theory of human adaptation and change in the electronic era must, therefore, consider the dynamic interplay of technological developments and a variety of psychosocial and structural determinants.

Albert Bandura is David Starr Jordan Professor of Social Science in Psychology at Stanford University. He was elected to the presidencies of the American Psychological Association, Western Psychological Association, and Honorary President of the Canadian Psychological Association. He is a proponent of a social cognitive theory that accords a central role to cognitive, vicarious, self-regulatory, and selfreflective processes in sociocognitive functioning. His book Social Foundations of Thought and Action: A Social Cognitive Theory presents the conceptual framework and large body of knowledge bearing on this theory. His recent book Self-Efficacy: The Exercise of Control presents self-efficacy belief as the foundation of human agency.

Correspondence concerning this article should be addressed to $\mathrm{Al}$ bert Bandura, Department of Psychology, Stanford University, Stanford, CA 94305-2130, USA (tel. + $1650725-2409$, fax +1 650725 5699, e-mail bandura@psych.stanford.edu). 
Social cognitive theory provides an agentic conceptual framework within which to study how electronic technologies impact worldwide connectivity and personal and national lives (Bandura, 1986; 2001). People make choices and motivate and regulate their behavior on the basis of belief systems. Among the mechanisms of self-regulation none is more central or pervasive than beliefs of personal efficacy (Bandura, 1997). This belief system is the foundation of human agency. Unless people believe they can produce desired outcomes and forestall undesired ones by their actions they have little incentive to act or to persevere in the face of difficulties. Whatever other factors serve as guides and motivators, they are rooted in the core belief that one has the power to produce changes by one's actions. It is a key factor in how people construct and live their lives.

Personal goals and aspirations, rooted in a value system, provide further incentives and guides for action. People also regulate their life course by the outcomes they expect their efforts to produce. These outcomes may be the expected material costs and benefits, positive and negative social effects and one's self-evaluation. After people adopt personal standards they do things that give them self-satisfaction and self-worth and refrain from behaving in ways that bring self-reproof. Personal development and change would be easy if there were no impediments to surmount. How people view the opportunities and obstacles in their environment shapes the courses their lives take.

Self-efficacy is a key determinant because it affects behavior both directly and by its influence on these other determinants. Efficacy beliefs determine goals and aspirations (Bandura, 1991b; Locke \& Latham, 1990). The stronger the perceived efficacy the higher the goal challenges people set for themselves and the firmer their commitment to them. Efficacy beliefs shape the outcomes people expect their efforts to produce (Bandura, 1997). Those of high efficacy expect favorable outcomes; those of low efficacy expect their efforts to yield poor results. Efficacy beliefs also determine how obstacles and impediments are viewed. People of low efficacy focus on costs and risks to be avoided rather than on opportunities (Krueger \& Dickson, 1993; 1994). They are easily convinced of the futility of effort in the face of impediments. Those of high efficacy view impediments as surmountable through self-development and perseverant effort.

Numerous large-scale meta-analyses have been conducted on findings from studies involving diverse populations, with diverse experimental and analytic methodologies applied across diverse spheres of functioning at both the individual and collective level (Boyer et al., 2000; Holden, 1991; Holden, Moncher, Schinke, \& Barker, 1990; Moritz, Feltz, Fahrbach, \& Mack, 2000; Multon, Brown, \& Lent, 1991; Sadri \& Robertson, 1993; Stajkovic \& Lee, 2001; Stajkovic \& Luthans, 1998). The converging evidence from these diverse lines of research verify that efficacy beliefs contribute significantly to the quality of human functioning.

People are producers as well as products of their social systems. Therefore, they have a hand in shaping their personal lives and the social and economic life of their society. Social cognitive theory extends the conception of human agency to collective agency (Bandura, 1997, 2001). People's shared belief in their combined power to achieve desired results is a key ingredient of collective agency. Perceived collective efficacy raises people's vision of what they wish to achieve, enhances motivational commitment to their missions, strengthens resilience to adversity, and enhances performance accomplishments.

Increasing complexities in technologies, social systems and the international economy present new dynamic realities demanding higher-order types of competencies. For example, in the modern workplace sweeping changes in technologies are mechanizing many of the everyday transactions and activities that were formerly done manually. In contemporary production systems, people manage computer-controlled machines that perform most of the routine work. We retool our production machines by changing the computer software. We design and test things using computer graphics rather than construct prototypes. The offices of today are run, in large part, by computerized informationmanagement systems.

New technologies are displacing traditional jobs even in the delivery of services. We bank with automatic tellers, talk to recording machines that shepherd us through tortuous paths, pump gas from computerized equipment monitored remotely, and shop online for all sorts of goods by pushbutton. Bar code scanners tied to automated inventory management systems reorder merchandise without requiring inventory clerks and purchasing agents. The diverse activities of everyday life are now being increasingly conducted via transactions through online automated systems.

Korbin (1998) illustrates the staggering implications of what will be routine commercial transactions in the electronically integrated cyberworld. A German teenager buys, from a French virtual music store, a $C D$ stored in a music company's computer in Ireland that is downloaded from a Web site in India, and paid for with electronic funds deposited in a bank in the Cayman Islands. This simple purchase is conducted entirely 
through electronic transfer of information around the world with no shipment of a physical product or exchange of paper currency. How does one track, measure and regulate national economies? Who has jurisdiction over online activities when the cyberworld is disconnected from national territories? Will the distribution of transactions across diverse locations in the cyberworld produce global governance under international rules? If nonterritorial modes of governance are created, how will national sovereignty be linked to them?

\section{Educational Self-Development and Self-Renewal}

The historical transition from the industrial to the information era has profound implications for educational systems. In the past, youth with limited schooling could get well-paying industrial and manufacturing jobs requiring minimal cognitive skills. Such options are rapidly shrinking. The emerging opportunities require high-level cognitive skills and self-regulatory capabilities to fulfill complex occupational roles and to manage the intricate demands of contemporary life.

The hope and future of people in a knowledge-based global society that is rapidly changing reside in their capacities for continual self-development and self-renewal. Educational systems must change their emphasis from mainly imparting knowledge to teaching students how to educate themselves throughout their lifetime. They have to be adaptable and proficient self-directed learners. Education for self-directedness is now vital for a productive and innovative society.

Information technologies are altering educational systems. Students can now exercise substantial personal control over their own learning. In the past, their educational development was dependent on the quality of the schools in which they were enrolled. Students now have the best libraries, museums, and multimedia instruction at their fingertips through the global internet for educating themselves independently of time and place. This shift in locus of initiative involves a major reorientation in students' conception of education in which they are agents of learning not just recipients of information.

Electronic media do more than just expand access to vast bodies of information. They also serve as a convenient vehicle for building virtual social networks for creating shared knowledge through collaborative learning and problem solving (Robey, Khoo, \& Powers, 2000). Through interactive electronic networking, people link together in dispersed locales, exchange information, share new ideas, and work collaboratively on projects. Cross pollination of ideas through worldwide connectivity can boost creativity synergistically in the co-construction of knowledge.

Information technologies are a tool not a panacea. They are only useful to those who choose to use them productively. Internet tutors can do little if students cannot motivate themselves to take advantage of what these systems have to offer. Students must develop skills in regulating the motivational, emotional and social determinants of their intellectual functioning, as well as the cognitive aspects. Efficacious self-regulators gain knowledge, skills and intrinsic interests in intellectual matters. Weak self-regulators achieve little self-development (Zimmerman, 1990).

Self-regulatory skills alone are not enough. They will contribute little if students cannot get themselves to apply those skills persistently in the face of difficulties, stressors and competing attractions. Firm belief in one's self-management efficacy provides the staying power. The stronger the students' perceived efficacy to manage their own learning, the higher their aspirations and accomplishments (Zimmerman \& Bandura, 1994; Zimmerman, Bandura, \& Martinez-Pons, 1992). Perceived self-efficacy for self-regulated learning enhances perceived selfefficacy to use the internet which, in turn, predicts success in managing internet-based self-instruction (Joo, Bong, \& Choi, 2000). In research on knowledge construction through the internet, students with a high sense of selfregulatory efficacy are the one's who make the best use of internet-based instruction (Debouski, Wood, \& Bandura, 2001). Those of low perceived efficacy for self-directed learning do not achieve much progress.

There is an educational disconnect between the rapidly evolving information technologies and the deficient development of students' high-level competencies and self-directive capacity. The efficacy impediment to adoption of information technologies is a systemic problem not just a personal one. School administrators and teachers who have a low sense of efficacy to manage computerized systems find them intimidating and make poor use of them (Hill, Smith, \& Mann, 1987).

The educational enterprise has diverse developmental aims. The cognitive aim cultivates cognitive competencies, knowledge and meanings. The self-regulatory aim develops self-management skills for self-development and continual self-renewal. The valuational aim fosters adoption of personal standards and core values. The social aim promotes prosocialness and a sense of civic responsibility. The affective aim fosters self-eval- 
uative and emotional well-being. The performance aim develops the operational abilities to translate knowledge into productive courses of action. These various facets of human development are intertwined. Development of these multifaceted competencies requires a multifaceted approach with instructional technologies used mainly for the things they can do well.

Evolving technologies are intricately woven into the fabric of social and institutional systems. Depending on their nature, these systems facilitate or impede the adoption of technological innovations. Therefore, how well nations develop their talent and provide enabling and supportive social systems are key factors in national technological capabilities. Given the critical role of psychosocial factors in the adoption and diffusion of innovations (Bandura, 1986; Rogers, 1995), one must guard against placing excessive hope in the technology itself.

Learners need live mentors to help build their selfregulatory efficacy, cultivate their aspirations, and to find meaning and direction in their intellectual pursuits. They need to learn media literacy skills on how to filter the avalanche of information, to analyze and evaluate it, and how to convert reliable information into knowledge and wisdom (Hobbs, 1998). The content of early schooling is perishable and long forgotten. But the valuational and self-regulatory capabilities last a lifetime as personal resources for continued self-development.

The development of internet literacy also holds high priority. We are entering a new era in which the construction of knowledge will rely increasingly on electronic inquiry. At present, about $50 \%$ of information is available solely in electronic form. Before long, most information will be available only in electronic form. Those lacking internet literacy will be cut off from critical information and disadvantaged in managing their daily life. Constructing knowledge through internetbased inquiry is a complex task. Information seekers face an avalanche of information in diverse sources of varying quality. Small changes in strategies can lead down radically different information pathways. It is hard to know whether one is on the right track or on an unproductive one. Knowing how to access, process, and evaluate this glut of information is vital for knowledge construction and cognitive functioning. People who doubt their efficacy to conduct productive inquiries and to manage the electronic technology, quickly become overwhelmed by the informational overload. Social cognitive theory provides guides for building the personal efficacy and cognitive skills needed to use the internet productively and creatively (Debouski, Wood, \& Bandura, 2001).
The globalization of knowledge is altering the nature of higher educational systems and their practices. The university of this electronic era will continue to play a central role in generating knowledge, promoting informative syntheses, and aiding the search for meaning through discoursive and reflective learning processes. But its teaching function will be more socially distributed and internationalized. Life in a knowledge-based society requires a highly educated citizenry capable of continual self-renewal through lifelong learning to manage the accelerated pace of informational and technological change. Mass social need calls for learning systems that can educate people worldwide. To fulfill this challenge, higher educational systems will have to change some of their structures, roles, and functions and enlarge the spectrum of people they serve.

Universities are beginning to extend their reach with internet courses offered independently or by pooling their intellectual resources in consortiums with other universities, libraries, museums and academic publishing houses in internet spin-off companies (Arenson, 2000). To augment the interpersonal dimension in distance learning, the more intensive online modes of instruction include video interactivity supplemented with local tutorial support systems in distant sites. Universities are also undertaking a new social application function by forming partnerships with industries that create and merchandise the products of patented scientific.discoveries. Some of the higher education is being conducted on a large scale by national virtual universities that enable students to structure academic programs from a vast array of courses available in the cyberworld rather than in physical academic sites (Guri-Rosenblit, 1999). One such European model enlists the best professorial talent and didactic resources of a consortium of 40 public universities for their online academy conducted from the mainline University of Rome (Garito, 1999). New commercial enterprises are springing up that provide programs for professional upgrading and instruction in the more technically oriented fields to serve the specialized vocational needs of society. Through these diverse means, people worldwide who would otherwise be excluded from adequate education can have access to it.

The changes in educational agency, scope, and function are not without potential problems, however. There is concern about the fragmentation and standardized packaging of knowledge into saleable courseware. Information technology is not only a tool of dissemination. The medium can shape the pedagogy. Market-driven systems will favor the online pedagogy that is most marketable. There is also concern over constraining the free 
exchange of knowledge if universities claim proprietorship over scientific discoveries in their laboratories for commercial purposes. As previously noted, education includes much more than acquisition of information. Human values, meanings, intellectual perspectives and civic commitments are fostered through immersion in inquiring communities rather than just by private reflection on external input. The challenge is to exploit the benefits of information technologies without embracing an insulated, socially disembodied cognitivism.

\section{Occupational Self-Regulation}

A major part of people's daily life is spent in occupational activities. These pursuits do more than provide income for one's livelihood. They serve as a major source of personal identity, self-evaluation and social connectedness. Self-directedness is becoming a key factor in occupational life as well. In the past, employees learned a given trade and performed it much the same way during their lifetime in the same organization. The modern workplace requires a highly skilled, flexible workforce to meet diversified and rapidly changing job demands. Much of the world of work is now structured so that employees assume operational control in flexible self-managed teams (Beyerlein \& Johnson, 1994). With the fast pace of change, knowledge and technical skills are quickly outmoded unless they are updated to fit the new technologies. Employees have to take charge of their self-development for a variety of positions and careers over the full course of their worklife (Bandura, 1997). The capacity for self-directedness is, of course, an essential personal resource in telework arrangements, where occupational activities are conducted at home or in a local facility. Under these arrangements, which are on the rise, people have to take charge of their own worklife.

Perceived self-efficacy affects, in diverse ways, the acceptance and use of electronic technologies in occupational pursuits. To begin with, students' beliefs in their efficacy shape their career choice and development (Betz, 2000; Lent, Brown, \& Hackett, 1994). The higher the people's perceived efficacy to fulfill educational requirements and occupational roles the wider the career options they seriously consider pursuing, the greater the interest they have in them, the better they prepare themselves educationally for different occupational careers, and the greater their staying power in chosen challenging pursuits. Students beliefs about their occupational efficacy and job preferences get formed at a surprisingly early age (Bandura, Barbaranelli, Caprara, \& Pastorelli, 2001).

Women and ethnic minorities constitute over half of the college population. Our society would have to draw on the talents of women and minorities to maintain its scientific, technological and economic viability. But our socialization practices undermine their efficacy for technological and scientific careers (Bussey \& Bandura, 1999; Betz \& Hackett, 1981). They tend to shun these types of occupational pursuits. Our societal response to this predicament is to import high-tech foreign nationals rather than grow our own from the untapped national source of talent.

Efficacy beliefs to master technological developments affect well-being and productivity in the modern workplace as well. Managers and employees of low computer efficacy learn little from computer-based tutorials and resist adopting new technologies (Ellen, 1988; Hill et al., 1987; Jorde-Bloom \& Ford, 1988). During technological changeovers, those of high learning efficacy are more committed to change, more satisfied with their work and perform better (McDonald \& Siegall, 1992).

Many organizational activities will be increasingly performed by members of virtual teams working together from scattered locations through computer-mediated transactions. Working remotely with little direct supervision across time, space, and cultural orientations can be quite taxing. Employees with high perceived efficacy for remotely conducted collaborative work have more positive job attitudes and achieve higher job performances than those of low perceived efficacy (Staples, Hulland, \& Higgins, 1998).

\section{Organizational Productivity and Innovativeness}

Efficacious adaptability has also become a premium at the organizational level. Organizations must be continuously innovative to survive and prosper in the rapidly changing global marketplace. They face the paradox of preparing for change at the height of success. Many fall victim to the inertia of success. They get locked into the technologies and products that produced their successes and fail to change fast enough to the technologies and marketplaces of the future.

There has been a phenomenal growth of digital technologies in Silicon Valley. Silicon Valley is not a place (Bronson, 1999). It is a flourishing entrepreneurial subculture distributed around the San Francisco Bay Area (Lee, Miller, Hancock, \& Rowen, 2000). Innova- 
tiveness largely involves creative syntheses of existing knowledge into new ways of thinking and doing things (Bandura, 1986). There is extensive cross-pollination of ideas in this milieu through a fluid regional network in which individuals with diverse expertise exchange ideas freely, celebrate risk taking, and accept failure as a natural part of innovative success. Close ties to universities that spawn creative ideas and ready availability of venture capital financing create the climate for innovation and reinforce the entrepreneurial spirit.

Entrepreneurs have to be willing to invest a great deal of time, effort, and resources in endeavors strewn with dashed hopes and take risks under uncertainty. It requires a resilient sense of efficacy to persevere in the face of repeated failures and setbacks in the face of tough odds inherent in innovative pursuits. Venturers of high efficacy judge themselves better able to beat the odds than venturers of lower efficacy (Krueger, 1994). Among patent inventors, it is those of high efficacy who are likely to start new business ventures (Baron, 1998). Venturers who achieve high growth in companies they have founded, or transformed those they have bought have a clear vision of what they wish to achieve, a firm belief in their efficacy to realize it, set challenging growth goals, and come up with innovative production and marking strategies (Baum, 1994).

\section{Widening Gaps and Equitable Distribution of Benefits}

There is much talk that inequity of access to electronic technology will widen gaps between sectors within societies and across different societies. The less advantaged will be left farther and farther behind. Discussions of possible remedies focus heavily on providing access to the physical technologies. Before long, the functions of the computer and video systems will be merged into an integrated system that will be widely available. The major barriers to equity of opportunity will be mainly sociostructural rather than technological. If access to educational offerings and other valuable sources of information is market driven, the inequities will center on affordability.

The growing social and economic divide between rich and poor nations presents more daunting challenges to make globalization more inclusive and equitable. Electronic technologies are not only unaffordable to poor nations, but they usually lack the educational, communicational, organizational and service infrastructures and the energy technologies to adopt and manage digital systems. These deficits are not amenable to quick fixes. It requires heavy long-term investment of resources in poorer nations to reduce the educational divide needed to ensure that globalization creates a beneficial shared future.

Advocates promote new technologies but often ignore the sociostructural conditions that shape their use and impact on the society at large. As a result, innovations intended for the public good often exacerbate societal problems. Gotsch (1972) illustrates how the same agriculture innovation creates markedly different distribution of benefits in societies under different social structures. The example concerns the innovation of tube wells that enable farmers to grow a second crop using irrigation during the arid season.

In the social system of Pakistan, because of dissension among farmers who owned small farms, they could not pool their resources to purchase the innovation. Development agencies gave loans to the larger landholders, who installed the irrigation system with profitable results. None of the small landholders did so, with polarizing socioeconomic effects. In the cooperatively structured social system of Bangladesh, the owners of minifarms formed cooperatives and installed in partnership the technology they could not afford individually. They nearly doubled their profits. Thus, the same technology widened the disparity between social and economic classes in one society, but produced shared benefits in another one.

Failures to adopt new technological innovations are often attributed to contrarian dispositions of nonadopters. In many instances, the problem lies in sociostructural impediments rather than dysfunctional dispositions. For example, development agencies generally offer the greatest assistance to those who are better off and command the social influence to get preferential treatment. In an effort to produce more equitable benefits, Roling, Ascroft and Chege (1976) instructed resistant development agencies to identify less advantaged farmers who had consistently passed up agricultural innovations. After they were taught the innovation and given loans, virtually all adopted the innovation and passed it on to others.

All to often we take a narrow view of the diffusion of innovations. The spread of technologies in a society is a social and institutional matter, not just a technological one. One must look beyond the physical technology for guidance on how to achieve equitable benefits. The worth of innovations should be evaluated in terms of the social distribution of benefits as well as their aggregate utility. The values to which societies subscribe influence wheth- 
er new technologies are used in ways that make life better for everyone or create widening disparities between sectors of society.

A more fundamental value issue concerns the purposes to which human talent and advanced technologies are put. For the most part, globalization is used to move financial capital, production, and trade around the world. It has spawned a hard-driving, competitive lifestyle measured mainly by marketplace values. Some of the intense market activities promote lavish consumption that neither use our finite resources wisely nor lead to a better quality of life (Ehrlich, Ehrlich, \& Dailey, 1995). At the broader societal level, transnational market forces can erode or undermine valued cultural aspects of life when they are disregarded or considered detractors from profitability. Social bonds and civic commitments that lack marketability are especially vulnerable to erosion by global market forces. The specter of failure in the competitive global marketplace is often used to justify inequitable occupational and economic practices and neglect of social obligations that serve the common good.

There is more to society than the market place. Critics of globalization upbraid the presiders over transnational market forces for their failure to temper its excesses and to use it as a vehicle to better the human condition worldwide. They want it used globally for social ends as well to protect human rights and working conditions and to preserve the ecosystems needed to sustain a habitable global environment. European nations seem oriented toward a more balanced model of globalization designated as the "third way" to take advantage of its many benefits while preserving social and civic commitments to the society at large (Giddens, 2000). The benefits are promoted by investment in human enablement through education, equitable opportunity structures, and provision of necessary technical resources.

\section{Self-Regulation of Health}

The field of health is another area in which evolving technologies are having considerable impact. In recent years, there has been a major change in the conception of health from a disease model to a health model. It is just as meaningful to speak of levels of vitality and healthfulness as of degrees of impairment and debility. Human health is heavily dependent on lifestyle habits and environmental conditions (McGinnis \& Foege, 1993). As health economists amply document, medical care cannot substitute for healthful habits and environmental conditions (Fuchs, 1974; Lindsay, 1980). The structuring of health promotion should begin with goals, not means. If health is the goal, biomedical interventions are not the only means to it. From the biopsychosocial perspective, improving health habits and creating healthful living environments yields the large health benefits.

The behavioral codetermination of health enables people to exercise some control over their vitality and quality of health. By managing their health habits, people can live longer, healthier, and slow the process of aging. To stay healthy, people should exercise, refrain from smoking, reduce the amount of dietary fat, keep blood pressure down, and develop effective ways of coping with stressors. If the huge health benefits of these lifestyle habits were put into a pill, it would be declared a spectacular breakthrough in the field of medicine.

The sociocognitive approach to health promotion is designed to inform, enable, motivate, and guide people to adapt habits that promote health and reduce those that impair it (Bandura, 2000). The social utility of health promotion programs can be enhanced by a stepwise implementation model. In this threefold stepwise approach the level and type of guidance is tailored to people's selfmanagement capabilities and motivational preparedness to achieve desired changes. People with high self-efficacy and positive outcome expectations succeed with minimal guidance to accomplish the changes they seek. Those who have self-doubts about their personal efficacy to manage their health habits make half-hearted efforts to change and are quick to give up when they run into difficulties. They need additional support and guidance by interactive means to see them through tough times. Those who believe that their health habits are beyond their personal control need a great deal of personal guidance in structured mastery programs.

Societal efforts to get people to adopt healthful practices rely heavily on mass communications in health campaigns. Meyerowitz and Chaiken (1987) examined four mechanisms through which health communications could alter health habits: By transmission of factual information, fear arousal, change in risk perception, and enhancement of perceived personal efficacy to do what is needed. Health communications fostered adoption of preventive health practices to the extent they raised beliefs in personal efficacy. These findings indicate that the framing of health communications requires a change in emphasis from trying to scare people into to health to empowering them with the self-management skills and self-beliefs needed to exercise control over their health habits. 
Analysis of how mass media campaigns change health habits similarly reveal that these population-based approaches promote beneficial changes mainly in people with high perceived efficacy for self-management and positive expectations that personal changes will improve their health (Carey \& Carey, 1993; Maibach, Flora, \& Nass, 1991; Slater, 1989). Analysis of the impact of mass health campaigns further reveals that the translation of health knowledge to healthful habits is mediated through perceived self-efficacy (Rimal, 2000). The correlation of knowledge with healthful habits is increased among participants whose perceived efficacy is raised, but decreased among those whose self-efficacy is lowered.

The absence of individualized guidance limits the power of one-way mass communications. The revolutionary advances in interactive technology provide the means to increase the reach and productivity of health promotion programs. On the input side, the new technologies enable targeting and personally tailoring health communications to factors that are casually related to health behavior. These factors include sociodemographic status, efficacy beliefs, outcome expectations, and perceived impediments. Personalized communications are viewed as more relevant and credible, are better remembered and are more effective in influencing health behavior than general health messages (Kreuter, Strecker, \& Glassman, 1999).

On the behavioral adoption side, interactive technologies provide a convenient means of individualizing the type and level of guidance needed to bring the desired changes to fruition. For example, DeBusk and his colleagues have developed an effective self-management model for health promotion and risk reduction that combines knowledge of self-regulation with enabling interactivity through computer-assisted implementation (DeBusk et al.,1994).

With the aid of the self-management system a single implementer can help many people in workplaces and in their homes to reduce habits that place them at risk for disease (Bandura, 2000; DeBusk et al., 1994; Clark et al., 1997; West et al., 2000). In long-term follow-up of patients suffering from coronary artery disease, those receiving the standard medical care by their physicians showed no change or a worsening of their condition. In contrast, those aided in self-management of health habits achieved big reductions in risk factors (Haskell et al., 1994). They also had much less build-up plaque on artery walls, fewer coronary events, fewer hospitalizations for coronary heart problems and fewer deaths. Among patients who have already suffered a heart attack, the self-management system is more effective in reducing risk factors and increasing cardiovascular functioning than the standard medical post-coronary care (DeBusk et al., 1994).

The self-management system is well received because it is individually tailored to people's needs; provides continuing personalized guidance that enables people to exercise considerable control over their own change; it is a home-based program that does not require any special facilities, equipment, or attendance at group meetings that usually have high drop-out rates; it can serve large numbers of people simultaneously under the guidance of a single implementer; it is not constrained by time and place; it combines the high individualization of the clinical approach with the largescale applicability of the public health approach; and it provides valuable health-promotion services at low cost.

In the present applications the computer is used as a coordinating and mailing system for guiding and supporting personal change. By linking the interactive aspects of the self-management system to the internet, one can vastly expand its availability for preventive and remedial guidance to people wherever they may live. The connectivity and capability for individualized interactivity of online systems provide an electronic vehicle for telehealth promotion.

Telehealth services and online interactive health promotion is the wave of the future. People will be receiving medical consultation directly in the home with ongoing monitoring of their health status for tailoring and adjusting health regimens. Those in outlying clinics, remote regions, and underserved sectors of society can receive health services under the guidance of specialists (Jerome et al., 2000). Through internationalization of health information and global connectivity, the internet can deliver health services online worldwide unfettered by geographical constraints. This is not just a vision. An internet joint venture created by Stanford and Yale Universities now provides physicians and nurses globally with instant expert information on patient care and teleconsultation services (Hubbs et al., 1997).

With increased life expectancy, minor dysfunctions have more time to develop into chronic diseases. The shift in the weight of disease from acute to chronic maladies will force societies to redirect their effects from supply-side remedies aimed at containing costs to demand-side solutions that keep people healthy throughout their lifespan so they have no need for costly services. Otherwise, nations will be swamped with staggering health costs that consume valuable resources needed for national programs. 
Psychosocial programs provide the public health vehicle for health promotion and disease prevention. We can amplify our impact on human health by making creative use of evolving interactive technologies that expand the scope and strength of health promotion efforts. Psychosocial programs for health promotion will be increasingly implemented via interactive internet-based systems. Individuals at risk for health problems typically shun preventive or remedial health services, but they will pursue online individualized guidance because it is readily accessible, convenient, and provides a feeling of anonymity. For example, young women at risk of eating disorders reduce dissatisfaction with their weight and body shape and alter disordered eating behavior, through interactive internet-delivered behavioral guidance (Taylor, Winzelberg, \& Celio, 2001).

The internet is transforming traditional medical relationships and how and where medicine is practiced. People are assuming more active roles in their health life. There are now over 100,000 medical Web sites in the United States alone flooding the health care marketplace. People are going to their computers to learn about diseases, possible diagnoses for what ails them, checking out the effectiveness of alternative treatments, looking into medications and their side effects. Pharmaceutical companies are now advertising prescription drugs directly to the pubic. Some people are ordering medications via the internet. They are turning to online self-help groups for guidance and social support.

There is a downside to some of the internet health services. People are engaging in extensive self-medication with a vast array of over-the-counter drugs, nutritional supplements, herbal therapies, and superficial psychosocial remedies marketed by purveyors of quick fixes. These self-medications are not without negative side effects. Moreover, uninformed self-care may be used for symptom relief that delays diagnosis and treatment of the source of maladies. The internet provides a ready vehicle for scam artists to peddle fraudulent cures and health products. Much of the health information on the internet may be inaccurate, erroneous, misleading or fraudulent. People need to be taught how to access and critically evaluate online health services to ensure that they are benefited rather than harmed by them. This requires the development of consumer protection systems that evaluate the accuracy and reliability of internet health services and guarantee the privacy and security of personal health information.

\section{Internet Technology in Sociopolitical Change}

The internet technology is changing social and political processes. It provides vast opportunities to participate directly in sociopolitical matters of concern, and a ready vehicle for mobilizing grass-roots activity to promote desired changes in social practices and policies. The internet is swift, wide-reaching, and free of institutional controls. Political contests are shifting to the cyberworld where political pronouncements and partisan critiques are circulated instantly. The unfettered, pluralistic nature of the internet is also changing the locus of power of the news media. The cyberworld contains a multiplicity of voices. Online journalistic enterprises, serving diverse ideologies and vested interests, may eventually supplant oldline broadcast networks as the main purveyors of sociopolitical information.

There is much utopian talk of electronic democratization and the liberalizing force of the internet as a new political forum unimpeded by gatekeepers who command power. Here too, one must guard against excessive hope for a technological remedy for problems of political strife and representative governance. The internet technology distributes the capacity to communicate throughout society and across national borders. But it does not determine the quality of online communities and what gets communicated.

The online journalistic debut at the recent political convention in the United States hardly exemplified emancipation from the oldline broadcast gatekeepers and rekindling of political participation (Wayne, 2000). There was low public participation in the Websites and much of the online political discourse was rather sterile. As is usually the case, initial euphoria over the empowering effect of a tool gives way to sobering realization that sociocultural factors largely govern how that tool is used. Political Web sites are characterized more by insular polarization than by intelligent deliberation. In the chat rooms of everyday life, some of the discourse is edifying and enabling, but much of it is banal, misinformed, contentious and even hateful. More communication does not necessarily mean more enlightening discourse for human betterment.

Ready access to communication technologies will not necessarily enlist active participation unless people believe that they can achieve desired results by this means. Strong personal and collective efficacy determines whether people make their voices heard in cyberspace politicing and whether they play an active part in 
bringing about meaningful changes in their lives (Bandura, 1997; Newhagen, 1994a, 1994b). This is another sphere of life where perceived efficacy will shape how the internet changes the face of social activism.

The joint influence of collective political efficacy and trust in the governmental system predicts the form and level of political activity (Seligson, 1980; Wolfsfeld, 1986). People who believe they can achieve desired changes through their collective voice and view their governmental systems as trustworthy participate actively in conventional forms of political activities. Those who believe they can accomplish social changes by perseverant collective action, but view the governing systems and officeholders as untrustworthy favor more confrontive and coercive tactics. The politically apathetic have little faith that they can influence governmental functioning through collective initiatives and are disaffected from the political system.

\section{The Dark Side of Electronic Technologies}

The social benefits of electronic technologies do not come without costs. People are now becoming wired to their workplace, regardless of where they are. With wireless communication devises, that respect neither time nor place, worklife increasingly intrudes on familial, social, and recreational life. This creates new challenges to strike a balance between the competing priorities of life. Cellular devices are also intruding into and changing the quality of public spaces. Cellphone users impose their personal lives on public spaces much to the annoyance of those around them, especially when cellular behavior is flaunted with a sense of self-absorbed entitlement and personal importance. Electronic technologies are also eroding privacy in unprecedented ways. Based on internet transactions and browsing, people's financial and medical status and other details of their personal lives can be monitored, recorded, profiled, archived, and shared with or sold to third parties for marketing purposes or for other misuses. The selling of people's privacy is characterized euphemistically in Amazon.com's privacy policy as a "transferable business asset." For the most part, people are blissfully unaware that computers preserve electronic records, computer tracking systems can find the users and resurrect their online activities. In another form of personal invasiveness, wireless tracking chips embedded in wireless communication devices can pinpoint a person's whereabouts anywhere, anytime.
Rosen (2000) makes the interesting point that the most disquieting consequences of the erosion of privacy is that people will be viewed in terms of distorted personal identities constructed from fragmentary, decontextualized online activities. If people are to preserve some privacy and dignity they will have to reinstate control over the use of information about personal online behavior through technological, social, and legal remedies.

Online behavior differs from face-to-face behavior (Gackenbach, 1998; Kiesler, 1997). Anonymity and pseudonymity in interchanges in the cyberworld remove communication restraints, enlist wider participation in activities, beget freer expressions of personal views and elicit more intimate self-disclosure than in everyday relationships. The cyberworld self is clearly less restrained. In addition, social transactions in the cyberworld provide individuals with opportunities to explore different facets of personal identity unimpeded by the inhibiting force of status and power differentials (McKenna \& Bargh, 2000). But concealment and depersonalization can also bring out the worst in people by removing personal and social sanctions for pernicious conduct (Froomkin, 1999).

Social cognitive theory of moral agency identifies eight mechanisms by which moral self-sanctions are selectively disengaged from detrimental conduct (Bandura, 1991a, 1999). The moral disengagement may center on the cognitive restructuring of transgressive conduct into a benign or worthy one by moral justification, sanitizing euphemistic language, and advantageous comparison; disavowal of a sense of personal agency by diffusion or displacement of responsibility; disregarding or minimizing the injurious effects of one's actions; and attribution of blame to, and dehumanization of, those who are victimized.

Rubin (1994) describes certain characteristics of electronic technologies that increase propensity for these forms of moral disengagement. Transgressive acts can be performed in privacy and anonymity toward depersonalized or faceless victims located thousands of miles away. Unlike breaking into offices to steal files, which is difficult to execute and escape detection, one can do so electronically with trivial effort without apparent tracks and the theft leaves the owner's property still in place. The moral disconnect makes it easy to behave transgressively. Social remedies for moral disengagement in the cyberworld should make it difficult for people to remove humanity and sanctions from their conduct.

The internet was designed as a highly decentralized system that defies regulation. Because anybody can get into the act and nobody is in charge, internet freelancers can use this unfettered vehicle for destructive purposes. 
There are several unique features of electronic information technologies that make them perilous if used for harmful purposes. They are readily accessible, portable, easily implementable remotely by pushbutton, connected worldwide for far-reaching consequence, and they are exceedingly difficult to control. Societal vulnerabilities are enormously magnified because virtually all of the systems on which people depend in their everyday life are interdependently run by computer network systems. These can be easily knocked out, as shown by the computer student in the Philippines who wreaked havoc world-wide by crippling e-mail systems costing billions of dollars. Smart hackers can do much more serious damage. Cybercrime and cyberterrorism, enacted through the internet, is a dark side of the cyberworld that will increasingly command societal attention.

\section{Globalization of Televised Modes of Influence}

The globalization of televised modes of influence is another major way in which the revolutionary advances in communication technologies are altering societies. Humans have evolved an advanced capacity for observational learning (Bandura, 1986). This enables them to enhance their knowledge and competencies through information conveyed by the rich variety of models. In the past, modeling influences were largely confined to the styles of behavior and social practices in one's immediate community. The advent of television vastly expanded the range of models to which members of society are exposed day in and day out. By drawing on these modeled patterns of thought and behavior, observers transcend the bounds of their customary environment.

Because the symbolic environment occupies a major part of people's everyday lives, much of the social construction of reality and shaping of public consciousness occurs through electronic acculturation. A major significance of symbolic modeling lies in its tremendous scope and instructive power. Unlike learning by doing, which requires shaping individual actions through repeated consequences, in observational learning a single model can transmit new ways of thinking and behaving simultaneously to countless people in widely dispersed locales.

There is another aspect of symbolic modeling that magnifies its psychological and social impact. In their daily lives, people have direct contact with only a small sector of the environment. They work in the same setting, travel the same limited routes, visit the same places, and see the same set of friends and associates. Consequently, their conceptions of social reality are greatly influenced by vicarious experiences-what they see, hear, and read in the mass media-without direct experiential correctives. The more people's images of reality depend upon the media's symbolic environment the greater is its social impact (Ball-Rokeach \& DeFleur, 1976). Video systems feeding off telecommunications satellites have become the dominant vehicle for disseminating symbolic environments. New ideas, values, and styles of conduct are now being rapidly diffused worldwide in ways that foster a globally distributed consciousness.

Global broadcasts now show sociopolitical conflicts as they are happening. This makes televised modeling a more influential vehicle for political and social change. Braithwaite (1994) provides evidence that the speed with which Eastern European rulers and regimes were toppled by collective action was greatly accelerated by televised modeling. The timing and form of collective action is better predicted by the force of modeling than by social structural conditions. The tactic of mass action modeled successfully by East Germans was immediately adopted by others living under oppressive rule.

A mass uprising by citizens of Ivory Coast dislodged the dictator Gueï who declared himself a winner of an election he was losing in the ballot count. The protestors modeled the militant strategy after the popular revolt against Milosevic in Yugoslavia who tried to annul an election in which he was defeated (Onishi, 2000). In commenting on the influential role of televised modeling in the popular uprising, a student protestor remarked, "The mistake Gueï made was to let us watch scenes from Belgrade."

Once a collective strategy has been shown to work, it is widely modeled (Bandura, 1986). However, televised modeling of civic strife in contests of power is a double-edged sword. It can fortify social control as well as promote social change depending on the depicted consequences of militant sociopolitical action. The Chinese dissidents were also emboldened by the German modeled success of forceful collective action. But the publicized results were markedly different. The Chinese populace watched on $\mathrm{CNN}$ the militia breaking down doors and arresting student activists. Live portrayal of brutal arrests helped to curb the spread of the uprising.

The vast body of knowledge on modeling is being widely applied for personal development and change (Bandura, 1997; Rosenthal \& Stelfek, 1991). Symbolic modeling lends itself readily for society-wide applications through creative use of the electronic media. For example, the soaring population growth and the envi- 
ronmental devastation it produces is the most urgent global problem. Sabido (1981) drew on social cognitive principles in creating radio and television dramatic serials that are being applied internationally with notable success in stemming this massive tide. The story lines model family planning, women's equality, environmental preservation, and a variety of effective life skills. The dramatizations inform, enable, guide, and motivate people to effect personal changes and to alter detrimental societal norms and practices (Bandura, in press).

Worldwide applications of this creative format in Africa, Asia and Latin America are raising people's perceived efficacy to control their family lives, enhancing the status of women in familial, social, and educational life, increasing adoption of contraceptive methods, and lowering the rates of childbearing (Bandura, 2002; Singhal \& Rogers, 1999). A controlled study in Tanzania compared changes in family planning and contraception use in part of the country that received a radio dramatic series with the rest of the country that did not (Rogers et al., 1999). Families in the broadcast area adopted family planning and contraceptive methods at a higher rate than in the control part of the country. Story lines emphasizing safer sexual practices to prevent the spread of AIDS increased condom use and reduced the number of sexual partners (Vaughan et al., 2000). These macrosocial applications of media ingenuity in translating social cognitive principles into social practice illustrate how a small collective effort can make a huge difference in an urgent global problem.

\section{Underminers of Collective Efficacy in Changing Societies}

As already noted, life in the societies of today is increasingly shaped by transnational interdependencies (Keohane 1993; Koehane \& Nye, 1977). Because of extensive global interconnectedness, what happens economically and politically in one part of the world can affect the welfare of vast populations elsewhere. Remote transnational influences now have widespread local effects on people's occupational, social, and economic lives. Transnational forces are hard to disentangle let alone control. They challenge the efficacy of governmental systems to shape their own economic and national life. As the need for efficacious collective effort grows so does the sense of collective powerlessness.

Many of the contemporary conditions of life undermine the development of collective efficacy. There are no handy social mechanisms or global agencies through which people can shape and regulate transnational practices that affect their lives. As nations wrestle with the loss of control, the public expresses disillusionment and cynicism over whether their leaders and institutions can work for them to improve their lives.

It has become fashionable to proclaim the demise of nation states. Lie (1996) has argued convincingly that globalization has changed the power relations of nation states not rendered them irrelevant. Transnational systems still have to operate through national institutional frameworks, human resources and operational infrastructures. It is not as though there is little or nothing nations can do about transnational forces. Under the new globalized realities, nation states increase their controlling leverage by merging into larger regional units such as the European Union. Other regional nation states will be forced to merge into larger blocks, otherwise they will have little bargaining power in transnational relations. These regional marriages do not come without a price. Paradoxically, to gain international control nations have to negotiate reciprocal pacts that require some loss of national autonomy and changes in traditional ways of life (Keohane, 1993). Some sectors of the society gain from the pacts, others lose.

Modern life is increasingly regulated by complex technologies that most people neither understand nor believe they can do much to influence. The very technologies that people create to control their life environment can become a constraining force that, in turn, controls how they think and behave. The social machinery of society is no less challenging. Bureaucracies thwart effective social action. Many of the bureaucratic practices are designed more to benefit the people who run the social systems than to serve the public. Those who exercise authority and control wield their power to maintain their advantages (Gardner, 1972).

Social efforts to change lives for the better require merging diverse self-interests in support of common core values and goals. Disagreements among different constituencies create additional obstacles to successful collective action. The recent years have witnessed growing social fragmentation into separate interest groups, each exercising its own power. Pluralism is taking the form of antagonistic factionalism. In addition, mass migration of people fleeing tyranny or seeking a better life is changing cultural landscapes. As societies become more multiethnic and globalized they are harder to unite around a national vision and purpose. Identity politics, decrying the dilution of nationhood, are on the rise.

The magnitude of human problems also undermines efficacy to find solutions for them. Profound global 
changes arising from burgeoning populations, deforestation, desertification of croplands, ozone depletion and rapid extinction of species by razing their habitats are destroying the intertwined ecosystems that sustain life. Worldwide problems of growing magnitude instill a sense of paralysis that there is little people can do to reduce such problems. Global effects are the products of local actions. The strategy of, "Think globally, act locally," is an effort to restore in people a sense of efficacy that they can make a difference. We saw earlier how small collective efforts in macrosocial applications of social cognitive principles can have a huge impact on global problems.

\section{Concluding Remarks}

It is widely proclaimed that digital technologies are determining the very nature of society. This type of view, depicting technology as a powerful force operating unidirectionally disembodied from the sociostructural context, instills a sense of inevitability about the form and direction societal changes will take. These new technologies admittedly function as a prominent element within societal systems that reaches deep into people's daily lives. But embracement of technological determinism masks the social and valuational forces that shape the uses to which technologies are put. In this reciprocal interplay, technology both influences, and is influenced by, the nature of social life. Investments in enabling social aspects of societies are needed to ensure that information technologies and globalization serve as a positive force rather than a divisive one in human lives.

\section{Author's Note}

This article was presented as a Keynote Address at the conference "New Media in the Development of Mind" in Naples, Italy, October 2000.

Preparation of this article and some of the cited research were facilitated by grants from the Grant Foundation and the Spencer Foundation. Several sections of this article include revised and expanded material from "Social cognitive theory: An agentic perspective," in the Annual Review of Psychology (2001).

\section{References}

Arenson, K.W. (2000, April 3). Columbia in web venture to share learning for profit. The New York Times, p. A22.

Ball-Rokeach, S., \& DeFleur, M. (1976). A dependency model of mass media effects. Communication Research, 3, 3-21.
Bandura, A. (1986). Social foundations of thought and action: A social cognitive theory. Englewood Cliffs, NJ: Prentice-Hall.

Bandura, A. (1991a). Social cognitive theory of moral thought and action. In W.M. Kurtines \& J.L. Gewirtz (Eds.), Handbook of moral behavior and development (Vol. 1, pp. 45-103). Hillsdale, NJ: Erlbaum.

Bandura, A. (1991b). Self-regulation of motivation through anticipatory and self-regulatory mechanisms. In R.A. Dienstbier (Ed.), Perspectives on motivation: Nebraska symposium on motivation (Vol.38, pp.69-164). Lincoln: University of Nebraska Press.

Bandura, A. (1997). Self-efficacy: The exercise of control. New York: Freeman.

Bandura, A. (1999). Moral disengagement in the perpetration of inhumanities. Personality and Social Psychology Review. [Special Issue on Evil and Violencel, 3, 193-209.

Bandura, A. (2000). Health promotion from the perspective of social cognitive theory. In P. Norman, C. Abraham, \& M. Conner (Eds.), Understanding and changing health behaviour (pp. 299339). Reading, UK: Harwood.

Bandura, A. (2001). Social cognitive theory: An agentic perspective. In Annual review of psychology (Vol. 52, pp. 1-26). Palo Alto: Annual Reviews, Inc.

Bandura, A. (2002). Environmental sustainability through sociocognitive approaches to deceleration of population growth. In P. Schmuch \& W. Schultz (Eds.). The psychology of sustainable development (pp. 209-238). Dordrecht, the Netherlands: Kluwer.

Bandura, A., Barbaranelli, C., Caprara, G.V., \& Pastorelli, C. (2001). Self-efficacy beliefs as shapers of children's aspirations and career trajectories. Child Development, 72, 187-206.

Baron, R.A. (1998). Cognitive mechanisms in entrepreneurship: Why, and how, entrepreneurs think differently than other persons. Journal of Business Venturing, 13, 275-294.

Baum, J.R. (1994). The relation of traits, competencies, vision, motivation, and strategy to venture growth. Unpublished doctoral dissertation, University of Maryland.

Betz, N.E. (2000). Self-efficacy theory as a basis for career assessment. Journal of Career Assessment, 8, 205-222.

Betz, N.E. \& Hackett, G. (1981). The relationship of career-related self-efficacy expectations to perceived career options in college women and men. Journal of Counseling Psychology, 28, 399-410.

Beyerlein, M.M., \& Johnson, D.A. (Eds.). (1994). Advances in interdisciplinary studies of work teams (Vol. 1). Greenwich, CN: JAI.

Boyer, D.A., Zollo, J.S., Thompson, C.M., Vancouver, J.B., Shewring, K., \& Sims, E. (2000, June). A quantitative review of the effects of manipulated self-efficacy on performance. Poster session presented at the annual meeting of the American Psychological Society, Miami, FL.

Braithwaite, J. (1994). A sociology of modeling and the politics of empowerment. British Journal of Sociology, 45, 445-479.

Bronson, P. (1999). The nudist on the late shift. New York: Random House.

Bussey, K., \& Bandura, A. (1999). Social cognitive theory of gender development and differentiation. Psychological Review, 106, 676-713.

European Psychologist, Vol. 7, No. 1, March 2002, pp. 2-16 (C) 2002 Hogrefe \& Huber Publishers 
Carey, K.B., \& Carey, M.P. (1993). Changes in self-efficacy resulting from unaided attempts to quit smoking. Psychology of Addictive Behaviors, 7, 219-224.

Clark, M, Ghandour, G., Miller, N.H., Taylor, C.B., Bandura, A., \& DeBusk, R. (1997). Development and evaluation of a computer-based system for dietary maagement of hyperlipidemia. Journal of the American Dietetic Association, 97, 146-150.

Debowski, S., Wood, R.E., \& Bandura, A. (2001). Impact of guided mastery and enactive exploration on self-regulatory mechanisms and information acquisition through electronic search. Journal of Applied Psychology, 86, 1129-1141.

DeBusk, R.F., Miller, N.H., Superko, H.R., Dennis, C.A., Thomas, R.J., Lew, H.T., Berger III, W.E., Heller, R.S., Rompf, J., Gee, D., Kraemer, H.C., Bandura, A., Ghandour, G., Clark, M., Shah, R.V., Fisher, L., \& Taylor, C.B. (1994). A case-management system for coronary risk factor modification after acute myocardial infarction. Annals of Internal Medicine, 120, 721-729.

Ehrlich, P.R., Ehrlich, A.H., \& Daily, G.C. (1995). The stork and the plow: The equity answer to the human dilemma. New York: Putnam.

Ellen, P.S. (1988). The impact of self-efficacy and performance satisfaction on resistance to change. Dissertation Abstracts International, 48, 2106-2107A.

Froomkin, A.M. (1999). Legal issues in anonymity and pseudonymity. The Information Society, 15, 113-127.

Fuchs, V. (1974). Who shall live? Health, economics, and social choice. New York: Basic Books.

Gackenbach, J. (Ed.). (1998). Psychology and the internet: Intrapersonal, Interpersonal, and Transpersonal Implications. San Diego: Academic Press.

Gardner, J.W. (1972), In common cause. New York: W.W. Norton.

Garito, M.A. (1999, June). Teaching and learning in universities in the year 2000. Paper presented at the meeting of the International Conference on Distance Education, Vienna, Austria.

Gerbner, G. (1972). Communication and social environment. Scientific American, 227, 153-160.

Giddens, A. (2000). The third way: A renewal of social democracy. Oxford: Blackwell Publishers.

Gotsch, C.H. (1972). Technical change and the distribution of income in rural areas. American Journal of Agricultural Economics, 54, 326-341.

Guri-Rosenblit, S. (1999). The agendas of distance teaching universities: Moving from the margins to the center of higher education. Higher Education, 37, 281-293.

Haskell, W.L., Alderman, E.L., Fair, J.M., Maron, D.J., Mackey, S.F., Superko, H.R., Williams, P.T., Johnstone, I.M., Champagne, M.A., Krauss, R.M., \& Farquhar, J.W. (1994). Effects of intensive multiple risk factor reduction on coronary atherosclerosis and clinical cardiac events in men and women with coronary artery disease. Circulation, 89, 975-990.

Hill, T., Smith, N.D., \& Mann, M.F. (1987). Role of efficacy expectations in predicting the decision to use advanced technologies: The case of computers. Journal of Applied Psychology, 72, 307-313.

Hobbs, R. (1998). The seven great debates in the media literacy movement. Journal of Communication, XX, 16-32.
Holden, G. (1991). The relationship of self-efficacy appraisals to subsequent health related outcomes: A meta-analysis. Social Work in Health Care, 16, 53-93.

Holden, G., Moncher, M.S., Schinke, S.P., \& Barker, K.M. (1990). Self-efficacy of children and adolescents: A meta-analysis, $P_{S y-}$ chological Reports, 66, 1044-1046.

Hubbs, P.R., Tsai, M., Dev, P., Godin, P., Olyarchuk, J.G., Nag, D., Linder, G., Rindfleisch, T.C., \& Melmon, K.L. (1997). The Stanford health information network for education: Integrated information for decision making and learning. Journal of the American Medical Association, 279, 505-508.

Jerome, L.W., DeLeon, P.H., James, L.C., Folen, R., Erles, J., \& Gedney, J.J. (2000). The coming of age of telecommunications in psychological research and practice. American $P_{\text {sychologist, }} 55$, 407-421.

Joo, Y.J., Bong, M., \& Choi, H.J. (2000). Self-efficacy for self-regulated learning, academic self-efficacy, and internet self-efficacy in web-based instruction. Educational Technology Research \& Development, 48, 5-18.

Jorde-Bloom, P., \& Ford, M. (1988). Factors influencing early childhood administrators' decisions regarding the adoption of computer technology. Journal of Educational Computing Research, 4, $31-47$.

Keohane, R.O. (1993). Sovereignty, interdependence and international institutions. In L. Miller \& M. Smith (Eds.), Ideas and ideals: Essays on politics in honor of Stanley Hoffman (pp. 91-107). Boulder, CO: Westview Press.

Keohane, R.O., \& Nye, J.S. (1977). Power and interdependence: World politics in transition. Boston: Little, Brown.

Kielser, S. (Ed.). (1997). Culture of the internet. Mahwah, NJ: Erlbaum.

Korbin, S.J. (1998). You can't declare cyberspace national territory. In D. Tapscott, A. Lowy, \& D. Ticoll (Eds.), Blueprint to the digital economy (pp. 354-370). New York: McGraw-Hill.

Kreuter, M.W., Strecker, V.J., \& Glassmann, B. (1999), One size does not fit all: The case for tailoring print materials. Annals of Behavioral Medicine, 21, 276-283.

Krueger, N.F. (1994). Strategic optimism: Antecedents of perceived success probabilities of new ventures. Paper presented at the meeting of the Academy of Management, Dallas, Texas.

Krueger, N.F., Jr., \& Dickson, P.R. (1993). Self-efficacy and perceptions of opportunities and threats. Psychological Reports, 72 , 1235-1240.

Krueger, N., Jr., \& Dickson, P.R. (1994). How believing in ourselves increases risk taking: Perceived self-efficacy and opportunity recognition. Decision Sciences, 25, 385-400.

Lee, C.M., Miller, W.F., Hancock, M.G., \& Rowen, H.S. (Eds.). (2000). The Silicon Valley edge: A habitat for innovation and entrepreneurship. Stanford: Stanford University Press.

Lent, R.W., Brown, S.D., \& Hackett, G. (1994). Toward a unifying social cognitive theory of career and academic interest, choice, and performance. Journal of Vocational Behavior, 45, 79-122.

Lie, J. (1996). Globalization and its discontents. Contemporary sociology. 25, 585-587.

Lindsay, C.M. (Ed.).(1980). New directions in public health care (3rd. ed.). San Francisco: Institute for Contemporary Studies. 
Locke, E.A., \& Latham, G.P. (1990). A theory of goal setting and task performance. Englewood Cliffs, NJ: Prentice-Hall.

Maibach, E., Flora, J., \& Nass, C. (1991). Changes in self-efficacy and health behavior in response to a minimal contact community health campaign. Health Communication, 3, 1-15.

McDonald, T., \& Siegall, M. (1992). The effects of technological self-efficacy and job focus on job performance, attitudes, and withdrawal behaviors. The Journal of Psychology, 126, 465-475.

McGinnis, J.M., \& Foege, W.H. (1993). Actual causes of death in the United States. Journal of the American Medical Association, 270, 2207-2212.

McKenna, K.Y.A., \& Bargh, J.A. (2000). Plan from cyberspace: The implications of the internet for personality and social psychology. Personality and Social Psychology Review, 4, 57-75.

Meyerowitz, B.E., \& Chaiken, S. (1987). The effect of message framing on breast self-examination attitudes, intentions, and behavior. Journal of Personality and Social Psychology, 52, 500-510.

Moritz, S.E., Feltz, D.L., Fahrbach, K.R., \& Mack, D.E. (2000). The relation of self-efficacy measures to sport performance: $A$ meta-analytic review. Research Quarterly for Exercise and Sport, $71,280-294$.

Multon, K.D., Brown, S.D., \& Lent, R.W. (1991). Relation of selfefficacy beliefs to academic outcomes: A meta-analytic investigation. Journal of Counseling Psychology, 38, 30-38.

Newhagen, J.E. (1994a). Self-efficacy and call-in political television show use. Communication Research, 21, 366-379.

Newhagen, J.E. (1994b). Media use and political efficacy: The suburbanization of race and class. Journal of the American Society for Information Science, 45, 386-394.

Onishi, N. (2000, October 26). Popular uprising ends junta's rule over Ivory Coast. The New York Times, p. A1.

Rimal, R.N. (2000). Closing the knowledge-behavior gap in health promotion: The mediating role of self-efficacy. Health Communication, 12, 219-237.

Robey, D., Khoo, H.M., \& Powers, C. (2000, March). Situated learning in cross-functional virtual teams. Professional Communication, 51-61.

Rogers, E.M. (1995). Diffusion of innovations (4th ed.). New York: Free Press.

Rogers, E.M., Vaughan, P.W., Swalehe, R.M.A., Rao, N., Svenkerud, P., \& Sood, S. (1999). Effects of an entertainment-education radio soap opera on family planning behavior in Tanzania. Studies in Family Planning, 30, 1193-211.

Roling, N.G., Ascroft, J., \& Chege, F.W. (1976). The diffusion of innovations and the issue of equity in rural development. In E.M. Rogers (Ed.), Communication and development (pp. 63-79). Beverly Hills: Sage.

Rosen, J. (2000). The unwanted gaze: The destruction of privacy in America. New York: Random House.

Rosenthal, T.L., \& Steffek, B.D. (1991). Modeling applications. In F.H. Kanfer \& A.P. Goldstein (Eds.), Helping people change (4th ed., pp. 70-121). Elmsford, NY: Pergamon.

Rubin, R. (1994). Moral distancing and the use of information technologies: The seven temptations. In J.M. Kizza (Ed.), Social and ethical issues of the computer revolution, (pp. 124-135). New York: McFarland.

Sabido, M. (1981). Towards the social use of soap operas. Mexico City: Institute for Communication Research.

Sadri, G. \& Robertson, I.T. (1993). Self-efficacy and work-related behavior: A review and meta-analysis. Applied Psychology: An International Review, 42, 139-152.

Seligson, M.A. (1980). Trust, efficacy and modes of political participation: A study of Costa Rican peasants. British Journal of Political Science, 10,75-98.

Singhal, A. \& Rogers. E.M. (1999). Entertainment-education: A communication strategy for social change. Mahwah, NJ: Erlbaum.

Skinner, C.S., Campbell, M.K., Rimer, B.K., Curry, S., Prochaska, J.O. (1999). How effective is tailored print communication? Annals of Behavioral Medicine, 21, 290-298.

Slater, M.D. (1989). Social influences and cognitive control as predictors of self-efficacy and eating behavior. Cognitive Therapy and Research, 13, 231-245.

Stajkovic, A.D., \& Lee, D.S. (2001). A meta-analysis of the relationship between collective efficacy and group performance. Paper presented at the national Academy of Management meeting, August, 2001, Washington, DC.

Stajkovic, A.D., \& Luthans, F. (1998). Self-efficacy and work-related performance: A meta-analysis. Psychological Bulletin, 124, 240-261.

Staples, D.S., Hulland, J.S., \& Higgins, C.A. (1998). A self-efficacy theory explanation for the management of remote workers in virtual organizations. Journal of Computer-Mediated Communication 3, Issue 4.

Taylor, C.B., Winzelberg, A., \& Celio, A. (2001). Use of interactive media to prevent eating disorders. In R. Striegel-Moor \& L. Smolak (Eds.), Eating disorders: New direction for research and practice (pp. 255-270). Washington, DC: American Psychological Association.

Vaughan, P.W., Roger, E.M., Singhal, A., \& Swalehe, R.M. (2000). Entertainment-education and HIV/AIDS prevention: A field experiment in Tanzania. Journal of Health Communications, 5, 81-100.

Wayne, L. (2000, August 19). Online coverage fell short of the hype. The New York Times, p. A10.

West, J.A., Bandura, A., Clark, E., Miller, N., Ahn, D., Greenwald, G., \& DeBusk, R.F. (2000). Self-efficacy predicts adherence to dietary sodium limitation in patients with heart failure. Unpublished manuscript, Stanford University.

Wolfsfeld, G. (1986). Evaluational origins of political action: The case of Israel. Political Psychology, 7, 767-788.

Zimmerman, B.J. (1990). Self-regulating academic learning and achievement: The emergence of a social cognitive perspective. Educational Psychology Review, 2, 173-201.

Zimmerman, B.J., \& Bandura, A. (1994). Impact of self- regulatory influences on writing course attainment. American Educational Research Journal, 31, 845-862.

Zimmerman, B.J., Bandura, A., \& Martinez-Pons, M. (1992). Selfmotivation for academic attainment: The role of self-efficacy beliefs and personal goal-setting. American Educational Research Journal, 29, 663-676. 